\title{
ANALISIS KEKERINGAN PADA DAERAH ALIRAN SUNGAI (DAS) BEDADUNG BERBASIS SISTEM INFORMASI GEOGRAFIS (SIG)
}

\author{
Ainur Rofiq Kurniawan ${ }^{a}$, M. Bisri ${ }^{\text {b }}$, Ery Suhartanto ${ }^{b}$ \\ ${ }^{a}$ Mahasiswa Magister Teknik Pengairan, Fakultas Teknik, Universitas Brawijaya, Malang \\ ${ }^{\mathrm{b}}$ Dosen Jurusan Teknik Pengairan, Fakultas Teknik, Universitas Brawijaya, Malang \\ e-mail : 'ropik.ngalam@gmail.com; ${ }^{\mathrm{b}}$ mbisri@ub.ac.id; ${ }^{\mathrm{b}}$ erysuhartanto@ub.ac.id
}

\begin{abstract}
ABSTRAK : Berkurangnya ketersediaan air terhadap kebutuhan merupakan salah satu indikator yang menunjukkan gejala kekeringan. Bencana kekeringan mendapat perhatian lebih dari Pemkab. Jember berupa arahan pengelolaan kawasan bencana kekeringan. Lokasi penelitian ini berada di DAS Bedadung dengan 13 pos hujan yang berada di hulu Stasiun AWLR Rowotamtu. Analisa kekeringan menggunakan metode Palmer Drought Severity Index yang berupa indeks yang menginformasikan tingkat kekeringan suatu daerah. Hasil studi menunjukan bahwa kekeringan dengan klasifikasi ekstrim kering terjadi terjadi pada bulan Juni sampai dengan bulan Oktober dengan nilai indeks kekeringan berkisar antara 1,82 (rerata Juni) sampai dengan -14,14 (rerata Oktober). Kecamatan Patrang, Jelbuk, Arjasa dan Panti termasuk wilayah yang mengalami kekeringan dengan durasi 5 bulan. Indeks kekeringan meteorologi metode Palmer dan indeks kekeringan hidrologi (nilai Transformasi Box Cox terstandarisasi (Z) Debit AWLR) mempunyai hubungan yang searah dan mempunyai tingkat hubungan yang kuat, dengan koefisien korelasi Pearson, $r=0,91$
\end{abstract}

Kata Kunci : Indeks Kekeringan Meteorologi, Indeks Kekeringan Hidrologi, Indeks Keparahan Kekeringan Palmer, SIG

\begin{abstract}
The reduced of water availability toward the needs is one thing that indicates the occurrence of a drought. The drought has received more attention from Government of Jember Regency in the form of a drought disaster area management direction. The location of this research is in the Bedadung River Basin with 13 rainfall station located in the upstream of Rowotamtu AWLR Station. Drought analysis uses the Palmer Drought Severity Index method in the form of index that informs the level of drought in an area. The results of the study showed that drought with extreme dry classification occurs from June to October with drought index values ranging from -1,82 (on June) to -14,14 (on October). Patrang, Jelbuk, Arjasa and Panti sub-districts are areas that have experienced drought with a duration of 5 months. Palmer method meteorological drought index and hydrological drought index (value of AWLR Discharge Standardized Box Cox Transformation (Z)) have unidirectional relationship and high degree of relationship, with the Pearson correlation coefficient, $r=0,91$
\end{abstract}

Keywords: Meteorological Drought Index, Hydrological Drought Index, Palmer Drought Saverity Index, GIS

Pemerintah Kabupaten Jember mempunyai perhatian terhadap bencana kekeringan. Hal ini dituangkan pada Peraturan Daerah (Perda) Pemerintah Kabupaten Jember No. 1 Tahun 2015 tentang Rencana Tata Ruang Wilayah (RTRW) Pemerintah Kabupaten Jember. Pada Pasal 38 ayat (1) huruf $g$, bencana kekeringan merupakan salah satu bencana alam yang menjadi perhatian Pemerintah Kabupaten Jember. Bentuk perhatian tersebut berupa arahan pengelolaan kawasan bencana kekeringan seperti yang disebutkan pada Pasal 38 Ayat (15) huruf a, yaitu melakukan identifikasi lokasi dan tingkat resiko kekeringan. Tingkat resiko kekeringan suatu daerah dapat diketahui dengan menghitung 
indeks kekeringannya kemudian digunakan untuk menditeksi, memantau dan mengevaluasi kejadian kekeringan. Indeks kekeringan yang dihasilkan dapat digunakan untuk menyusun informasi tentang kekeringan berupa intensitas, durasi, tingkat keparahan dan sebaran keruangan (spatial) (Hatmoko W., 2014). Sehingga dapat digunakan sebagai langkah antisipasi dalam menghadapi kekeringan (mitigation). Indeks kekeringan adalah komponen kunci untuk memantau kekeringan, berdasarkan variabel meteorologi atau hidrologi (Zengchao et al., 2016).

Palmer Drought Saverity Index adalah salah satu metode menghitung indeks kekeringan yang dikembangkan oleh Palmer (1965). Pada prinsipnya perhitungan metode Palmer ini didasarkan pada besarnya curah hujan dan kemampuan tanah dalam menampung air sesuai dengan jenis tanahnya. Palmer menggunakan model dua lapis tanah yaitu lapisan atas dan lapisan bawah yang di dasarkan pada metode Thornthwaite, masingmasing mempuyai kapasitas lapisan yang tersedia yaitu AWCs (ketersediaan air lapisan pertama) dan $\mathrm{AWCu}$ (ketersediaan air lapisan kedua) (Huang et al., 2011; Vasiliades dan Loukas, 2009). Metode Palmer didasarkan pada konsep pemasukan dan pengeluaran dari persamaan neraca air, yang juga dipengaruhi oleh data curah hujan dan suhu serta ketersediaan air tanah (Kao dan Govindaraju, 2010; Mishra dan Singh, 2010). Salah satu alasan digunakan Indeks Kekeringan Palmer karena indeks ini menilai kekeringan dari berbagai sumber pengamatan (Szep et al., 2005), selain itu metode ini merupakan standarisasi untuk iklim lokal sehingga dapat digunakan untuk semua negara dalam menunjukkan kekeringan relatif atau kondisi curah hujannya (Huang et al., 2011; Suryanti, 2008).

Sedangkan untuk analisa kekeringan hidrologi dapat dilakukan dengan memanfaatkan data hidrologi yang tersedia, yaitu muka air sungai atau data AWLR. Debit aliran sungai merupakan salah satu indikator kekeringan hidrologi yang mudah diamati di lapangan. Jika debit aliran sungai kecil, maka hal ini merupakan gejala adanya kejadian kekeringan. Selain itu menurut Loukas A. et al. (2007) data debit dari Stasiun AWLR dapat dinormalisasikan menggunakan transformasi Box Cox dan distandarisasikan sehingga mendapatkan indeks kekeringan hidrologi.

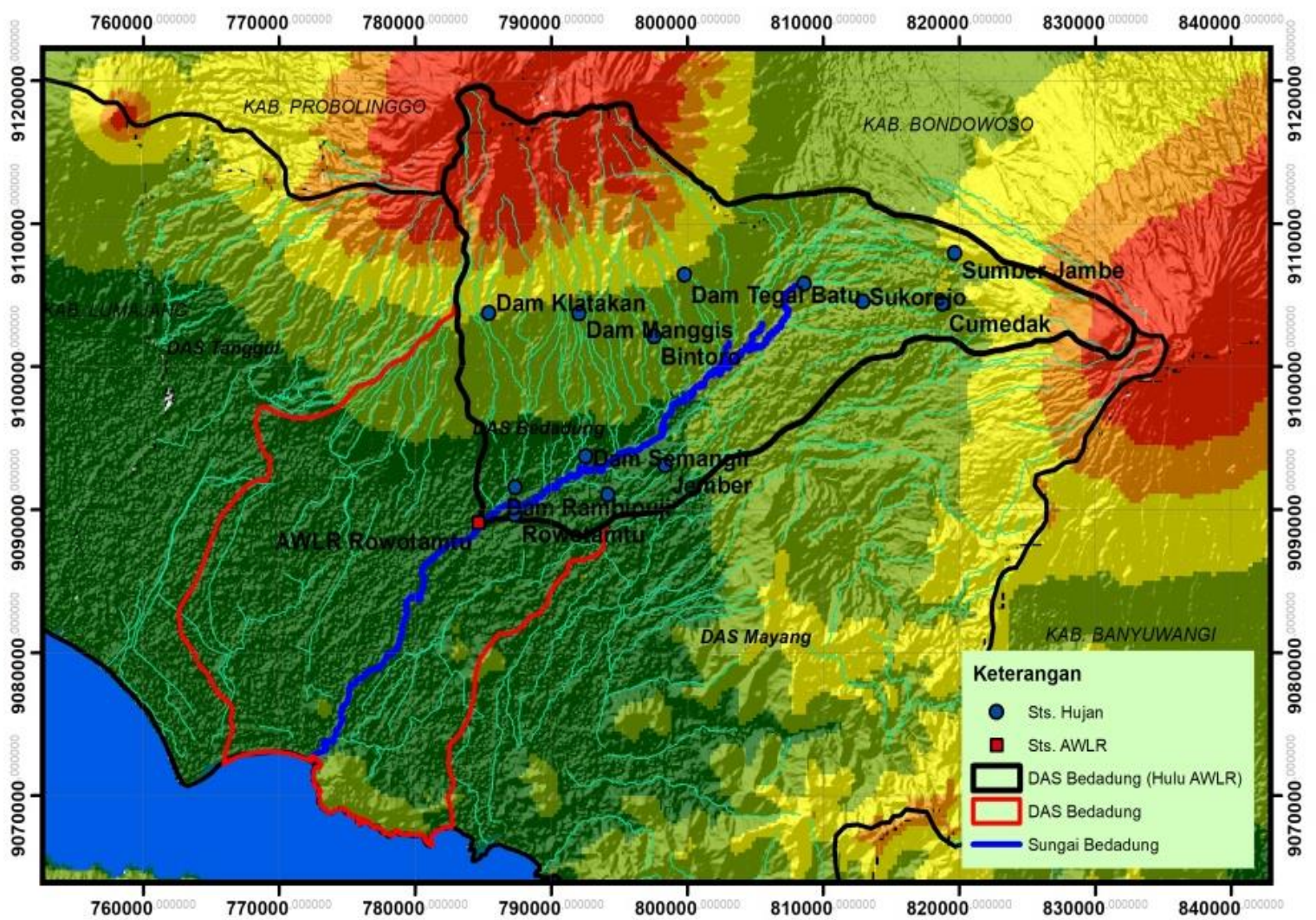

Gambar 1. DAS Bedadung (Hulu Stasiun AWLR Rowotamtu) Sumber : Dinas PU BM-SDA Kab. Jember dan Dinas PU SDA Prov. Jawa Timur 
Tujuan dari studi ini adalah memberikan gambaran sebaran kekeringan yang terjadi pada DAS Bedadung dengan menggunakan metode Palmer Drought Severity Index, mengetahui kondisi kekeringan hidrologi dan mengetahui hubungan antara indeks kekeringan meteorologi dengan kondisi kekeringan berdasarkan data hidrologi.

\section{METODE PENELITIAN}

\section{Lokasi Penelitian}

Studi penelitan ini mengambil lokasi di dalam Daerah Aliran Sungai (DAS) Bedadung yaitu DAS Bedadung bagian hulu stasiun AWLR Rowotamtu. Gambar 1 menjelaskan batas-batas wilayah hidrologi pada lokasi studi penelitian ini. Pada sebelah barat berbatasan dengan DAS Tanggul, sebelah timur berbatasan dengan DAS Mayang, sebelah utara berbatasan dengan Kabupaten Bondowoso dan sebelah Selatan berbatasan dengan DAS Bedadung bagian hilir stasiun AWLR Rowotamtu. Secara wilayah administrasi lokasi studi berada di Kabupaten Jember. Iklim di Kabupaten Jember adalah iklim tropis. Angka temperatur berkisar antara $24,40^{\circ} \mathrm{C}-$ $29,10^{\circ} \mathrm{C}$, dengan musim kemarau terjadi pada bulan Juni sampai bulan Oktober dan musim hujan terjadi pada bulan November sampai bulan Mei. Sedangkan curah hujan tahunan berkisar antara $924 \mathrm{~mm}$ sampai $4.915 \mathrm{~mm}$.

DAS Bedadung bagian hulu stasiun AWLR Rowotamtu sebagai wilayah studi ini memiliki luas seluas $804,6 \mathrm{~km}^{2}$ yang mencakup 11 kecamatan yaitu Kecamatan Panti, Sukorambi, Patrang, Kaliwates, Jelbuk, Arjasa, Sumbersari, Sukowono, Kalisat, Pakusari dan Sumberjambe. Jenis tutupan lahan pada lokasi studi ini terdiri dari hutan, semak belukar, perkebunan, pertanian, persawahan, dan pemukiman. Sedangkan tekstur tanah pada lokasi studi terdiri dari lempung berliat, lempung pasir halus, liat dan pasir halus.

\section{Pengumpulan Data}

Data-data yang dapat dikumpulkan untuk melakukan analisis atau perhitungan dalam studi ini adalah sebagai berikut: (1) Data curah hujan dari 13 stasiun hujan (2004-2018); (2) Data klimatologi dari 1 stasiun meteorologi, berupa data temperatur suhu (2004-2018); (3) Peta topografi; (4) Peta tata guna lahan (2010); (5) Peta batas DAS; (6) Peta jenis tanah dan tekstur tanah; dan (7) Data debit pada outlet wilayah studi yakni pos AWLR Rowotamtu.

\section{Metode Analisa \\ Pengujian Data}

Pengujian data ini bertujuan untuk mengetahui kualitas data dan keandalan data yang digunakan dalam analisis perhitungan. Kualitas dan keandalan data yang baik sangat erat kaitannya dengan kesesuaian hasil analisis perhitungan dengan keadaan yang sesungguhnya. Pengujian data untuk data hujan adalah uji konsistensi metode kurva ganda, sedangkan data debit AWLR menggunakan uji konsistensi metode Rescaled Adjusted Partial Sums (RAPS) dan uji stasioneritas untuk data suhu.

\section{Analisa Data Curah Hujan}

Data curah hujan dari stasiun hujan terpilih digunakan untuk mendapatkan hujan rerata daerah menggunakan metode Poligon Thiessen. Sehingga mendapatkan pola curah hujan selama periode data yang didapat.

Dari data curah hujan penakar terpilih dapat dilakukan analisa hujan rerata bulanan untuk setiap stasiun hujan, sehingga dapat mengetahui pola dan variasi curah hujan rerata bulanan. Selain mengetahui pola dan variasi curah hujan, dengan menggunakan metode Mohr, kita dapat membedakan keadaan hujan menjadi bulan basah $(P \geq 100 \mathrm{~mm})$, bulan kering $(P \leq 60 \mathrm{~mm})$ dan bulan lembab $(60-$ $100 \mathrm{~mm})$.

\section{Suhu Udara}

Tidak semua pos stasiun hujan memiliki data suhu udara. Sehingga perlu melakukan pendugaan suhu dari stasiun terdekat dengan cara mempertimbangkan faktor ketinggian tempat. Untuk penyesuaian ini digunakan cara Mock (1973).

$$
\Delta t=0,006\left(z_{1}-z_{2}\right){ }^{\circ} \mathrm{C}
$$

Persamaan (1) di atas adalah, perbedaan suhu antara stasiun pengukuran dengan stasiun pengukuran yang dianalisa $(\Delta t)$, elevasi stasiun ukur suhu $\left(z_{1}\right)$, elevasi stasiun analisa $\left(z_{2}\right)$

\section{Menghitung Selisih $\boldsymbol{P}$ dan $\boldsymbol{E P}$ tiap Bulan}

Perhitungan evapotranspirasi potensial $(E P)$ dihitung dengan metode Thornthwaite. Evapotranspirasi potensial tersebut berdasarkan suhu udara rerata bulanan. Adapun persamaanya adalah sebagai berikut: 


$$
\begin{aligned}
E P_{x}= & 16 \times\left[\frac{10 T \mu}{I}\right]^{\alpha} \\
E P= & f \times E P x \\
I \quad= & \sum_{m=1}^{12}\left(\frac{T}{5}\right)^{1,514} \\
a \quad= & (6,75 \cdot 10-7) \cdot I^{3}-(7,71 \cdot 10-5) \cdot I^{2}+ \\
& (1,792 \cdot 10-2) \cdot I+0,49239
\end{aligned}
$$

Persamaan (2) s/d (5) di atas menyebutkan $\left(T_{m}\right)$ suhu udara rata-rata bulanan $\left({ }^{\circ} \mathrm{C}\right)$, sedangkan koefisien koreksi diambil dari tabel koefisien penyesuaian menurut bujur dan bulan $(f)$ kemudian dikalikan dengan evapotranspirasi potensial yang belum disesuaikan sehingga mendapatkan nilai evapotranspirasi potensial $(E P)$.

Menghitung selisih nilai $P$ dan $E P$ bertujuan untuk mengetahui apakah bulan tersebut termasuk dalam bulan basah atau bulan kering. Apabila $(P-E P)>0$ atau disebut sebagai bulan basah dan apabila $(\mathrm{P}-\mathrm{EP})<0$ disebut sebagai bulan kering

\section{Kapasitas Penyimpanan Air (Water Holding Capacity)}

Pendugaan kapasitas menyimpan air (WHC) dilakukan secara tidak langsung. Cara ini memerlukan peta tanah (tekstur tanah) dan peta tutupan lahan serta tabel konversi Thornthwaite Mather. Adapun cara pendugaan yang dilakukan dengan cara: (1) Penggambaran peta poligon thiessen; (2) Melakukan overlay peta sebaran hujan, peta jenis tanah (tekstur tanah diketahui) dan peta tutupan lahan; (3) Melakukan perhitungan luas setiap bentuk penggunaan lahan pada setiap polygon dengan mempertimbangkan perbedaan tekstur tanahnya; (4) Dengan Tabel Pendugaan Kapasitas Air tersedia berdasarkan kombinasi tipe tanah dan vegetasi, diperoleh nilai air tersedia dan panjang perakaran, maka nilai $W H C$ didapat. Dengan memanfaatkan sistem informasi geografis (SIG) pendugaan kapasitas menyimpan air (WHC atau $S T_{O}$ ) dapat dilakukan.

\section{Indeks Kekeringan}

Indeks kekeringan metode Palmer Drought Saverity Index (Palmer) adalah salah satu metode untuk mengindentifikasi tingkat keparahan kekeringan yang terkandung dalam seri data hujan pada suatu wilayah. Untuk mendapatkan indeks kekeringan metode Palmer dibutuhkan beberapa parameter utama. Parameter utama tersebut adalah evapotranspirasi, pengisian lengas tanah, kehilangan kelembapan tanah. Untuk mendapatkan parameter-parmeter tersebut dapat mengunakan neraca air metode Thornthwaite. Selain parameter utama yang tersebut di atas, neraca air metode Thonthwaite dapat menghasilkan parameter lain yang terkait dengan perhitungan antara lain evapotranspirasi potensial, pengisian lengas ke dalam tanah potensial, aliran permukaan potensial, dan kehilangan tanah potensial.

Tahapan-tahapan analisa indeks kekeringan metode Palmer dapat dijelaskan sebagai berikut: (1) menentukan harga dari keempat konstanta iklim, yaitu koefisien evapotranspirasi $(\alpha)$, koefisien pengisian $(\beta)$, koefisien limpasan $(\gamma)$, koefisien kehilangan air $(\delta)$ dan karakteristik iklim ( $\kappa)$; (2) Menentukan nilai Climatically Appropriate for Existing Conditions (CAFEC), nilai ini adalah dugaan parameter-parameter evapotranspirasi, runoff, recharge, presipitasi dan loss, dimana secara klimatologis sesuai dengan kondisi waktu dan tempat yang diuji; (3) Menentukan periode kehilangan hujan (d); (4) Mendapatkan nilai rata-rata $d$ sehingga mendapatkan nilai mutlak (D); (5) Mendapatkan nilai pendekatan kedua terhadap nilai faktor $K\left(\kappa^{\prime}\right)$; (6) Mendapatkan nilai karakter iklim sebagai faktor pembobot $(K)$; (7) Melakukan perhitungan indeks penyimpangan (anomali) lengas $(Z)$; dan (8) Mendapatkan nilai indeks kekeringan metode Palmer.

\section{Pemetaan Indeks Kekeringan}

Setelah mendapatkan nilai indeks kekeringan selanjutnya nilai indeks kekeringan tersebut ditampilkan dalam peta sebaran kekeringan. Klasifikasi indeks kekeringan dapat dilihat berdasarkan Tabel 1. Penggambaran peta sebaran kekeringan menggunakan software ArcGIS 10.2 dengan metode interpolasi IDW. 
Tabel 1. Kelas Indeks Kekeringan Palmer dan Sifat Cuaca

\begin{tabular}{|c|c|}
\hline $\begin{array}{c}\text { Indeks } \\
\text { Kekeringan }\end{array}$ & Sifat Cuaca \\
\hline$\geq 4.00$ & Ekstrim Basah \\
\hline $3.00-3.99$ & Sangat Basah \\
\hline $2.00-2.99$ & Agak Basah \\
\hline $1.00-1.99$ & Sedikit Basah \\
\hline $0.50-0.99$ & Awal Selang Basah \\
\hline $0.49-(-0.49)$ & Normal \\
\hline$-0.50-(-0.99)$ & Awal Selang Kering \\
\hline$-1.00-(-1.99)$ & Sedikit Kering \\
\hline$-2.00-(-2.99)$ & Agak Kering \\
\hline$-3,00-(-3,99)$ & Sangat Kering \\
\hline$\leq-4.00$ & Ekstrim Kering \\
\hline
\end{tabular}

Sumber: Palmer (1965)

\section{Analisa Kekeringan Hidrologi}

Menurut Loukas A., et al. (2007) data debit dari Stasiun AWLR dapat dinormalisasikan menggunakan transformasi Box Cox dan distandarisasikan sehingga mendapatkan indeks kekeringan hidrologi. Nilai Transformasi Box Cox $(Y)$ didapatkan dengan rumus sebagai berikut:

$$
Y=\left\{\begin{array}{l}
\frac{X^{\lambda}-1}{\lambda} ; \lambda \neq 0 \\
\ln (X) ; \lambda=0
\end{array}\right.
$$

Nilai Transformasi Box Cox terstandarisasi $(Z)$ dengan rumus sebagai berikut:

$$
Z=\frac{Y-\bar{Y}}{\sigma_{Y}}
$$

Dari data debit AWLR $(X)$ dengan bantuan Minitab 18 akan didapatkan nilai $\lambda$ yang akan digunakan sebagai koefisisen untuk melakukan transformasi data debit AWLR menjadi nilai $(Y)$. Selanjutnya data hasil transformasi tersebut dikurangi nilai rata-rata transformasi data debit AWLR $(\bar{Y})$ dibagi standar deviasi transformasi data debit AWLR $\left(\sigma_{Y}\right)$ sehingga didapatkan nilai yang telah distandarisasikan $(Z)$. Nilai $Z$ ini dapat digunakan sebagai indeks kekeringan hidrologi Analisa Hubungan Indeks Kekeringan Meteorologi dengan Hidrologi

Analisa hubungan antara indeks kekeringan meterologi dengan hidrologi dapat dilakukan dengan menggunakan analisa korelasi dan regresi. Analisa korelasi adalah alat statistik yang digunakan untuk mengetahui derajat hubungan linier antara variable yang satu dengan lainnya untuk mencari arah dan kuatnya hubungan antara dua variabel (Qudratullah, M. F., 2014). Analisa korelasi menggunakan koefisien korelasi product moment Pearson (r). Selain analisa korelasi, hubungan kedua indeks kekeringan dapat menggunakan analisa regresi dengan membangun grafik $x y$ scatter untuk menilai seberapa erat hubungan antara hujan penakar dengan data debit.

\section{HASIL DAN PEMBAHASAN Pengujian Data}

Dari pengujian 13 data curah hujan, 1 data suhu dan 1 data debit AWLR mendapatkan hasil data-data tersebut mempunyai kualitas dan keandalan data yang baik sehingga dapat dipergunakan.

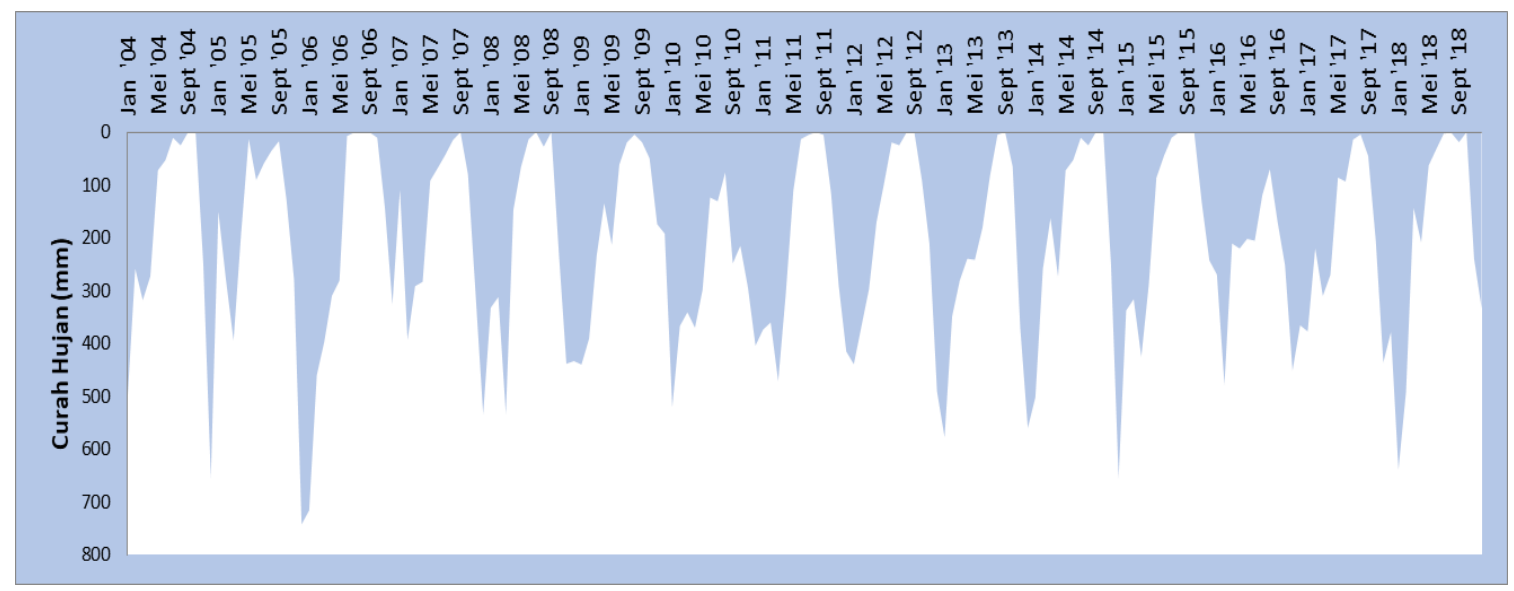

Gambar 2. Grafik Curah Hujan Rerata Daerah Bulanan pada DAS Bedadung (2004-2018) Sumber: Hasil Analisa 


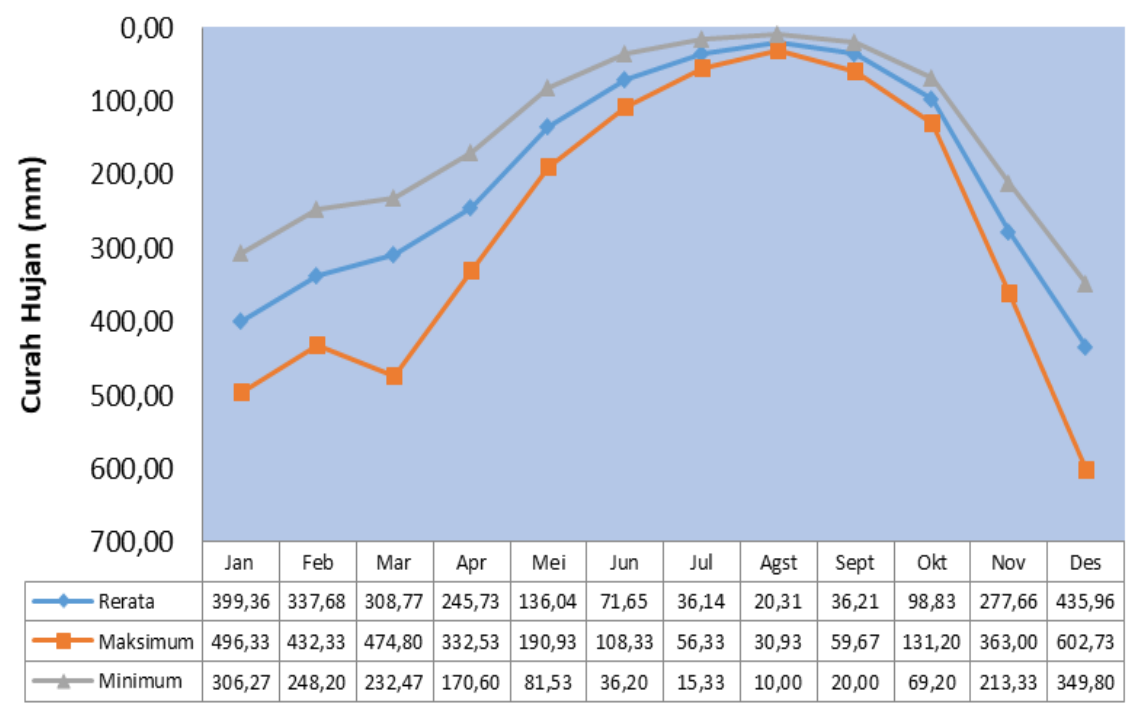

Gambar 3. Pola Curah Hujan Rerata Bulanan pada DAS Bedadung Sumber: Hasil Analisa

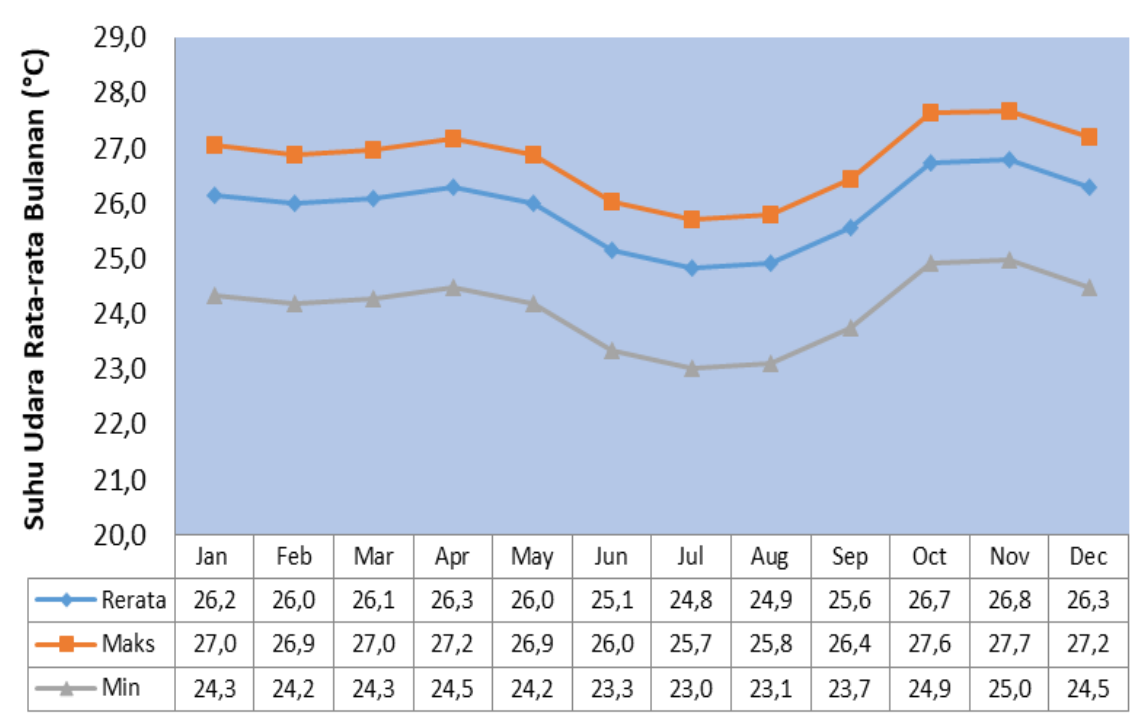

Gambar 4. Pola Suhu Udara Rata-rata Bulanan DAS Bedadung Sumber: Hasil Analisa

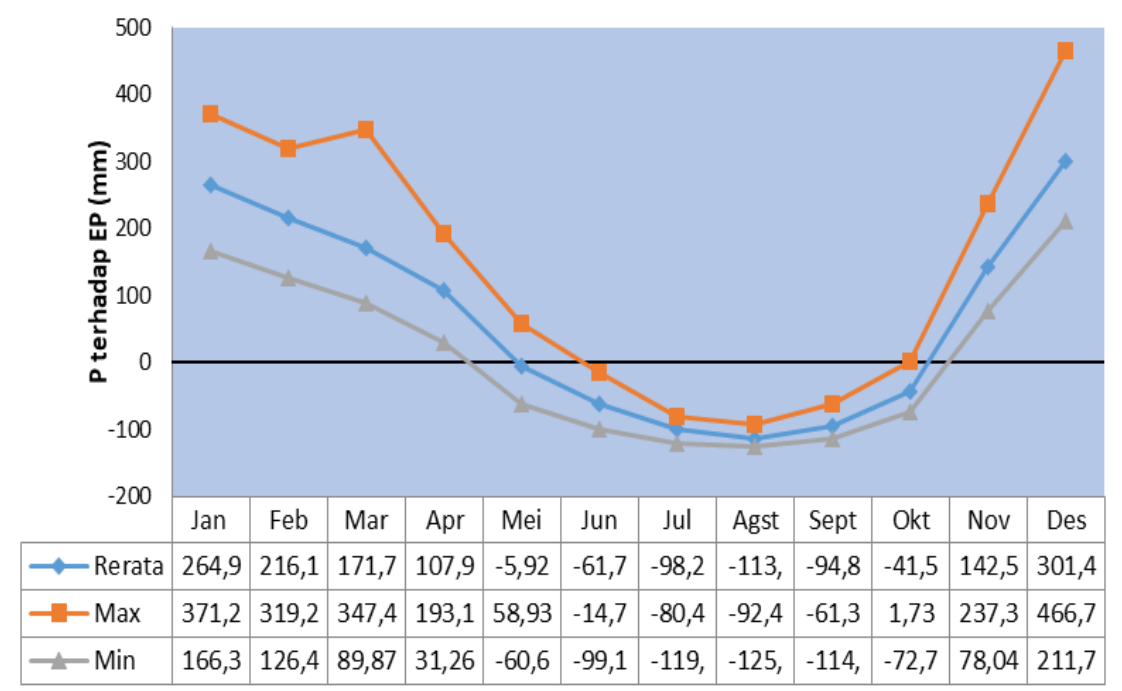

Gambar 5. Grafik Curah Hujan $(P)$ terhadap Evapotranspirasi Potensial $(E P)$ Sumber: Hasil Analisa 


\section{Analisa Data Curah Hujan}

Gambar 2 menggambarkan kondisi curah hujan sepanjang 15 tahun yang mempunyai pola yang mirip setiap tahunnya yaitu mempunyai curah hujan rendah di pertengahan tahun dan curah hujan tinggi di awal serta akhir tahun.

Untuk mengetahui pola curah hujan bulanan selama satu tahun dapat dilakukan dengan menggunakan hujan rerata bulanan. Sehingga dapat mengetahui pola curah hujan rerata bulanan di daerah studi.

Gambar 3 menyajikan pola curah hujan rerata bulanan di lokasi studi. Dengan menggunakan kriteria metode Mohr, dapat disimpulkan terjadi bulan kering selama 3 bulan yaitu bulan Juli - September, 2 bulan lembab pada bulan Juni dan Oktober dan bulan basah selama 7 bulan yaitu bulan November Mei.

\section{Analisa Data Suhu}

Kebanyakan stasiun penakar hujan di Indonesia tidak disertai peralatan untuk mencatat suhu. Oleh karena itu perlu dilakukan penyesuaian menggunakan metode Mock, dengan cara melakukan pendugaan suhu terhadap Stasiun Hujan yang lain menggunakan perbedaan elevasi dengan Stasiun Cuaca Notohadinegoro.

Gambar 4 menyajikan suhu rata-rata bulanan yang didapatkan dari pendugaan suhu dari setiap stasiun penakar hujan di wilayah studi. Pola suhu udara rata-rata bulanan ini dapat diketahui adanya penurunan suhu pada bulan Juli - September dibandingkan bulan yang lain.

\section{Menghitung selisih $\boldsymbol{P}$ dan $E P$ tiap Bulan}

Besarnya nilai curah hujan $(P)$ yang dikurangkan dengan nilai evapotranspirasi potensial $(E P)$, kemudian selisih tersebut digunakan untuk menentukan nilai defisit dan surplus pada DAS Bedadung.

Gambar 5 meyajikan nilai rerata perhitungan selisih nilai curah hujan rerata bulanan dengan evapotranspirasi potensial rerata bulanan $(P-E P)$ pada DAS Bedadung, dapat memberikan gambaran bahwa di lokasi studi terjadi defisit air $(P-E P<0)$ selama 6 bulan antara bulan Mei - Oktober dan rentang bulan November - April terjadi surplus air $(P-$ $E P>0)$.

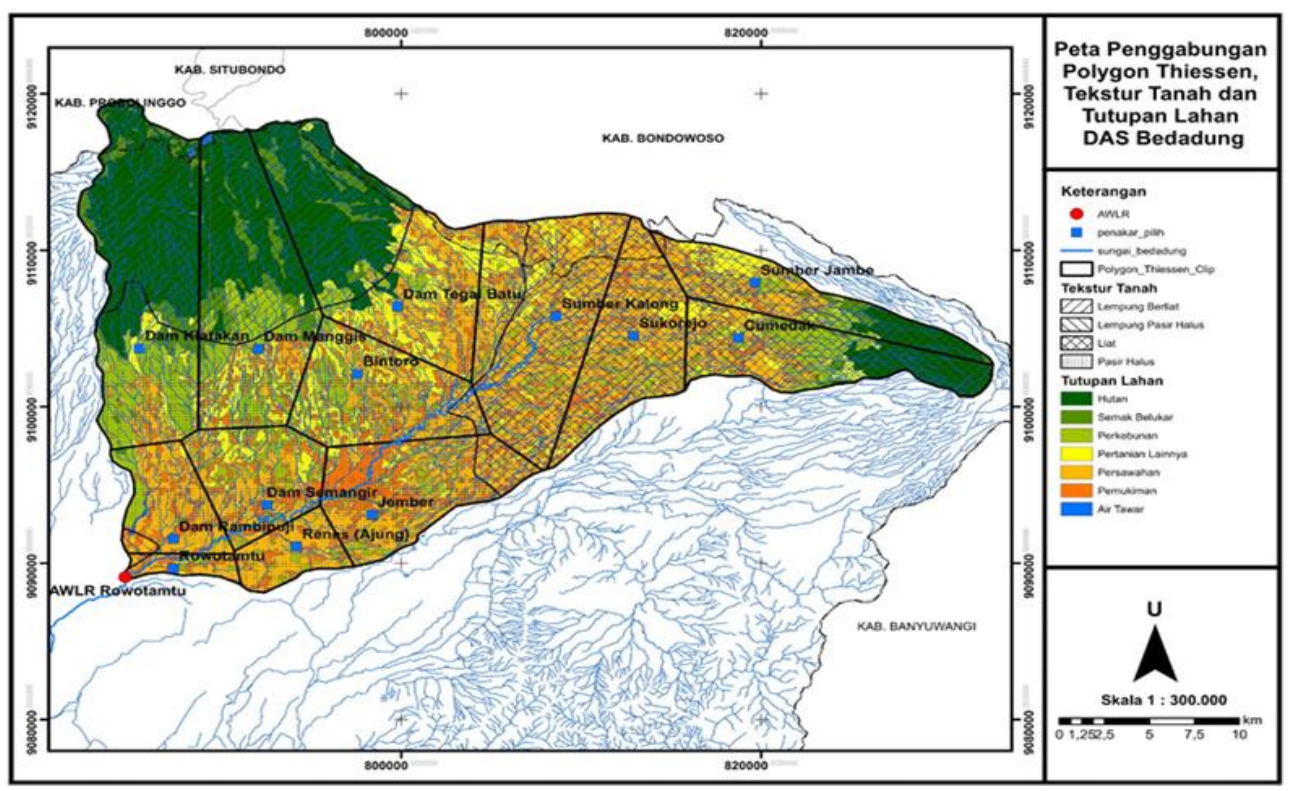

Gambar 6. Penggabungan Peta Stasiun Hujan, Tekstur Tanah dan Tata Guna Lahan Sumber: Hasil Tumpang Susun ArcGIS 10.2

Analisa Kapasitas Penyimpanan Air (Water Holding Capacity)

Nilai kelebihan tanah yang tertahan atau kelembapan tanah pada kapasitas lapang (STo) sama dengan kapasitas penyimpanan air atau Water Holding Capacity (WHC) (Jannah,
2015). Perhitungan nilai kapasitas penyimpanan air (WHC) diperhitungkan pada masing-masing sebaran stasiun penakar hujan di dalam wilayah studi. Dengan bantuan perangkat lunak ArcGIS 10.2, melakukan tahapan tumpang susun terhadap Peta Poligon 
Theissen, Tekstur Tanah dan Tutupan Lahan, seperti yang ditampilkan pada Gambar 6. Peta gabungan hasil tumpang susun tersebut menghasilkan luasan tutupan lahan terhadap tekstur tanah dimasing-masing luasan poligon theissen. Kemudian luasan tersebut dijadikan prosentase wilayah. Untuk mendapatkan nilai $W H C$, prosentase wilayah hasil tumpang susun dikalikan dengan nilai panjang zona perakaran dan air tersedia. Sehingga didapatkan nilai WHC di setiap Stasiun Penakar Hujan.

Tabel 2. Rekapitulasi Nilai Indeks Kekeringan Metode Palmer Rerata Bulanan pada DAS Bedadung

\begin{tabular}{|c|c|c|c|c|c|c|c|c|c|c|c|c|}
\hline \multirow{2}{*}{ Tahun } & \multicolumn{12}{|c|}{ Bulan } \\
\hline & Jan & Feb & Mar & Apr & Mei & Jun & Jul & Agst & Sept & Okt & Nov & Des \\
\hline Bintoro & 15,011 & 13,300 & 10,905 & 8,600 & 2,741 & $-4,046$ & $-9,650$ & $-14,308$ & $-14,147$ & $-7,644$ & 3,292 & 13,457 \\
\hline Cumedak & 24,471 & 22,880 & 22,041 & 18,573 & 9,915 & 1,465 & $-6,750$ & $-12,156$ & $-12,777$ & $-7,440$ & 7,326 & 21,531 \\
\hline Dam Klatakan & 14,698 & 13,000 & 10,601 & 8,270 & 0,657 & $-7,941$ & $-14,238$ & $-20,393$ & $-20,439$ & $-12,507$ & 1,856 & 13,939 \\
\hline Dam Manggis & 19,930 & 20,343 & 17,307 & 12,526 & 5,108 & $-4,515$ & $-9,570$ & $-15,881$ & $-17,976$ & $-10,644$ & 6,204 & 22,173 \\
\hline Dam Rambipuji & 14,401 & 13,833 & 11,897 & 10,407 & 7,099 & 0,055 & $-5,362$ & $-9,626$ & $-10,157$ & $-4,883$ & 3,961 & 14,847 \\
\hline Dam Semangir & 17,282 & 16,230 & 14,184 & 12,966 & 8,455 & 0,484 & $-5,305$ & $-10,128$ & $-10,699$ & $-4,635$ & 7,401 & 19,154 \\
\hline Dam Tegal Batu & 23,030 & 20,981 & 16,408 & 10,017 & 1,520 & $-5,477$ & $-10,548$ & $-18,022$ & $-19,764$ & $-12,079$ & 1,516 & 14,766 \\
\hline Jember & 19,768 & 17,460 & 14,373 & 12,795 & 8,248 & 1,007 & $-4,245$ & $-10,118$ & $-14,922$ & $-10,148$ & 1,961 & 14,458 \\
\hline Renes (Ajung) & 15,335 & 13,783 & 10,991 & 8,806 & 5,745 & 0,285 & $-6,077$ & $-11,925$ & $-13,601$ & $-7,824$ & 3,336 & 13,242 \\
\hline Rowotamtu & 13,968 & 13,400 & 11,173 & 9,247 & 5,773 & $-1,970$ & $-7,937$ & $-12,447$ & $-13,804$ & $-7,559$ & 3,021 & 15,328 \\
\hline Sukorejo & 19,779 & 17,441 & 13,678 & 9,335 & 2,861 & $-1,195$ & $-5,850$ & $-11,374$ & $-11,992$ & $-7,772$ & 2,542 & 12,964 \\
\hline Sumber Jambe & 22,632 & 20,518 & 17,165 & 13,737 & 7,100 & $-0,356$ & $-6,593$ & $-11,813$ & $-12,080$ & $-4,146$ & 8,814 & 19,776 \\
\hline Sumber Kalong & 20,921 & 18,573 & 15,165 & 10,336 & 3,156 & $-1,408$ & $-6,321$ & $-10,813$ & $-11,515$ & $-7,857$ & 2,857 & 14,482 \\
\hline Rerata & 18,560 & 17,060 & 14,300 & 11,200 & 5,260 & $-1,820$ & $-7,570$ & $-13,000$ & $-14,140$ & $-8,090$ & 4,160 & 16,160 \\
\hline Status IK Palmer & EB & EB & EB & EB & EB & SK & EK & EK & EK & EK & EB & EB \\
\hline
\end{tabular}

Sumber: Hasil Analisa

\section{Indeks Kekeringan}

Tabel 2 menjelaskan terjadi bulan kering selama 5 bulan, dimulai dari rerata bulan Juni dengan kriteria Sedikit Kering $\left(I K M_{\text {Palmer }}=\right.$ 1,465) dan berakhir di rerata bulan Oktober dengan kriteria Ekstrim Kering $\left(I K M_{\text {Palmer }}=\right.$ 8,090). Nilai $I K M_{\text {Palmer }}$ paling rendah $=-14,140$ terjadi pada rerata bulan September.

\section{Pemetaan Indeks Kekeringan}

Selajutnya dilakukan tumpang susun antara peta sebaran indeks kekeringan bulanan dengan batas wilayah kecamatan tiap tahun. Sehingga kita mengetahui apakah wilayah kecamatan yang dinyatakan dalam Peraturan Daerah Kabupaten Jember No. 1 Tahun 2015 tentang Rencana Tata Ruang Wilayah Tahun 2015 - 2035 pasal 38 ayat (14) sebagai kawasan rawan bencana kekeringan mempunyai kesesuaian dengan analisa kekeringan menggunakan metode Palmer. Adapun wilayah tersebut adalah Kecamatan Patrang, Jelbuk, Arjasa dan Panti.
Gambar 7 menjelaskan semua wilayah kecamatan di wilayah studi mengalami kekeringan dengan durasi yang bervariasi. Kecamatan Panti, Patrang, Jelbuk dan Arjasa mempunyai durasi kekeringan selama 5 bulan. Sedangkan untuk wilayah kecamatan di dalam lokasi studi mempunyai durasi kekeringan selama 4 bulan.

Dari hasil analisa ke empat kecamatan tersebut termasuk wilayah yang mengalami kekeringan dengan durasi 5 bulan atau dengan kata lain mempunyai durasi paling lama daripada wilayah kecamatan lainnya. Oleh karena itu Peraturan Daerah Kabupaten Jember No. 1 Tahun 2015 tersebut telah sesuai memasukan Kecamatan Patrang, Jelbuk, Arjasa dan Panti termasuk sebagai kawasan rawan bencana kekeringan berdasarkan indeks kekeringan metode Palmer 

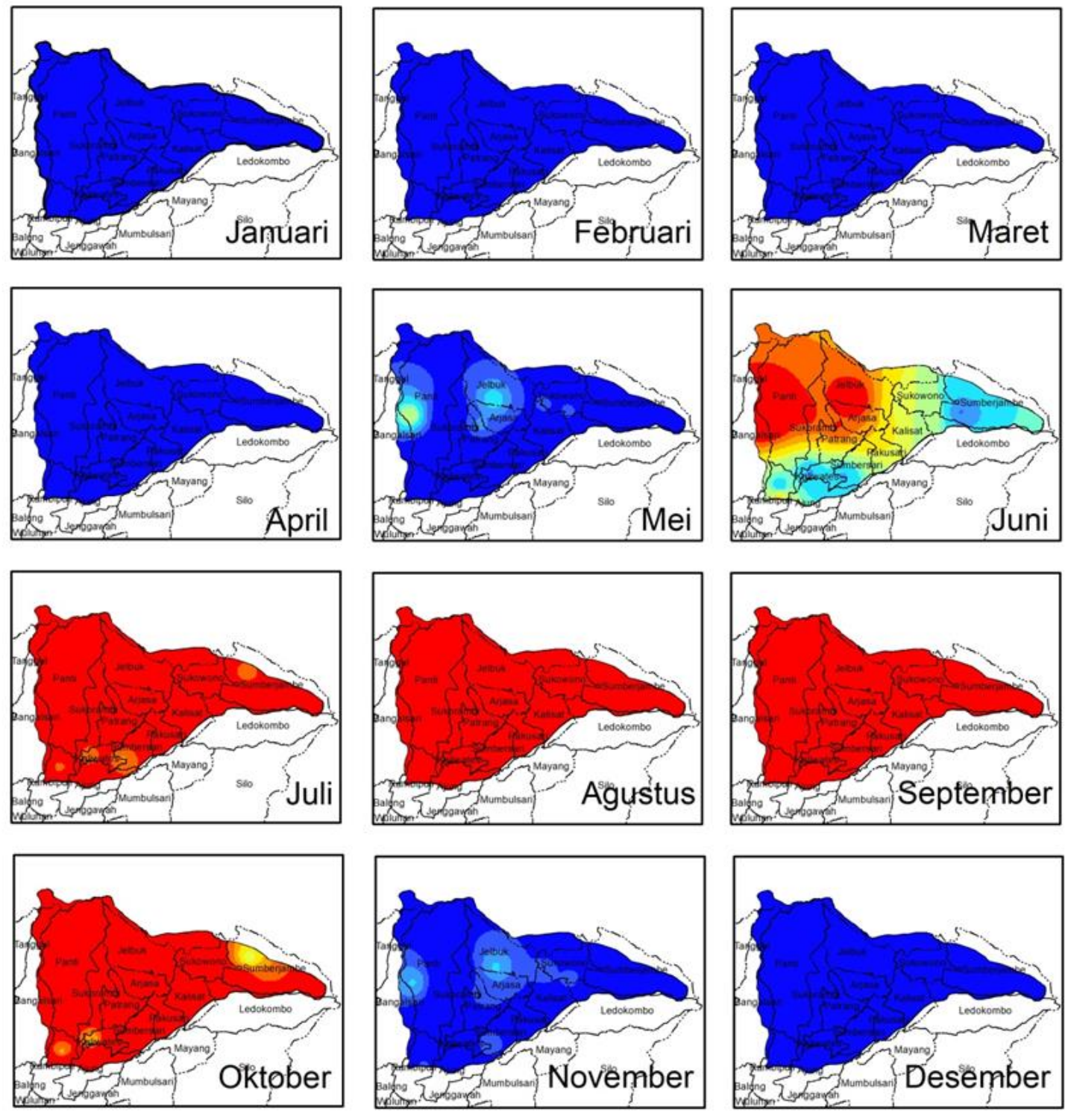

\section{Legenda}

Ekstrim Kering (<-4)
Sangat Kering $(-3 \mathrm{~s} / \mathrm{d}-3,99)$
Agak Kering $(-2 \mathrm{~s} / \mathrm{d}-2,99)$
$\square$ Sedikit Kering $(-1 \mathrm{~s} / \mathrm{d}-1,99)$
$\square$ Awal Selang Kering $(-0,5 \mathrm{~s} / \mathrm{d}-0,99)$
$\square$ Normal $(0,49 \mathrm{~s} / \mathrm{d}-0,49)$

$1: 1.000 .000$

$\begin{array}{llllll}0 & 5 & 10 & 20 & 30 & 40\end{array}$

Kilometers
Awal Selang Basah $(0,5 \mathrm{~s} / \mathrm{d} 0,99)$ Sedikit Basah (1 s/d 1,99) Agak Basah (2 s/d 2,99) Sangat Basah (3 s/d 3,99) Ekstrim Basah (>4)

\section{Peta Sebaran Kekeringan pada DAS Bedadung Rerata Bulan}

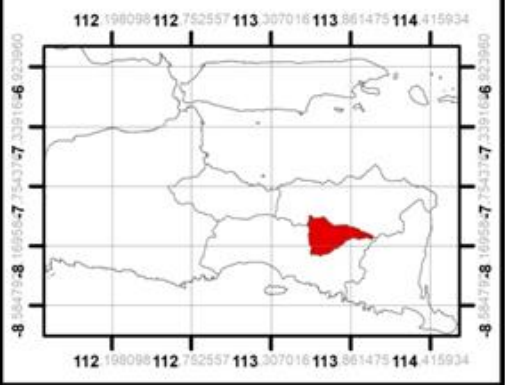

Gambar 7. Peta Sebaran Kekeringan Rerata Bulanan Tahun 2004 - 2018 terhadap Wilayah Kecamatan Sumber: Hasil Tumpang Susun ArcGIS 10.2 


\section{Analisa Hubungan Debit AWLR dengan curah hujan rerata daerah (Rainfall Area) Bulanan}

Gambar 8 menggambarkan bahwa pola curah hujan rerata daerah bulanan dengan data debit AWLR mempunyai kemiripan, saat terjadi bulan basah maka debit memiliki nilai yang lebih besar dibandingkan pada bulan kering.

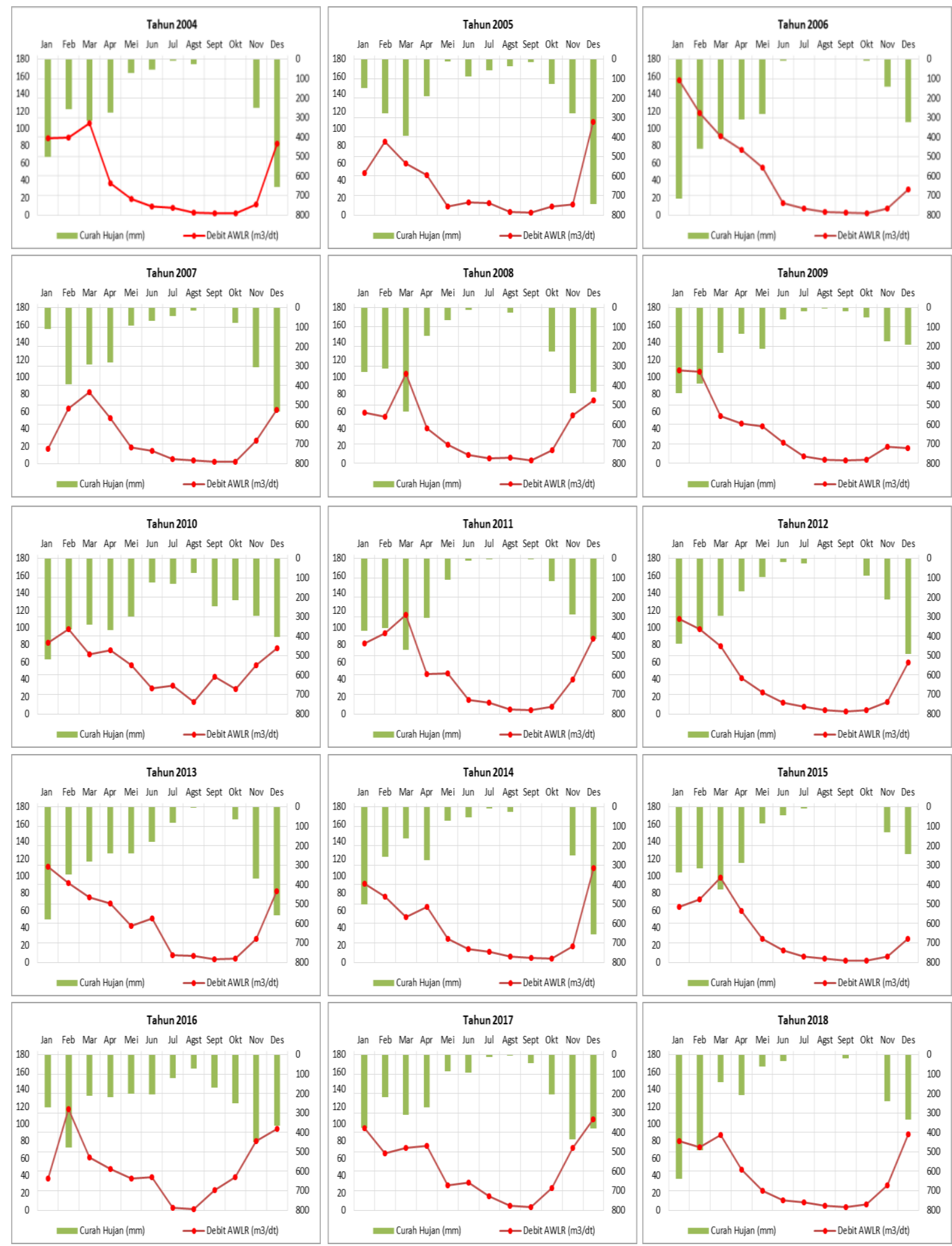

Gambar 8. Hubungan Hujan Rerata Daerah Bulanan dengan Debit AWLR Sumber: Hasil Analisa 


\section{Analisa Hubungan Indeks Kekeringan Meteorologi dengan Hidrologi}

Pada Tabel 3 berikut ini menampilkan rekapitulasi nilai indeks kekeringan metode Palmer pada DAS Bedadung setiap bulan selama tahun 2004 - 2018. Untuk mendapatkan nilai indeks kekeringan pada DAS Bedadung tersebut maka dilakukan perhitungan analisa wilayah dengan mengalikan nilai indeks kekeringan tiap stasiun penakar hujan selama tahun 2004 2018 dengan bobot luas wilayah sebaran poligon thiessen tiap stasiun penakar hujan.

Nilai Transformasi Box Cox terstandarisasi (Z) Debit AWLR dapat digunakan sebagai indeks kekeringan hidrologi (Loukas A. et al., 2007). Adapun nilai tersebut ditampilkan pada Tabel 4 berikut ini.

Tabel 3. Rekapitulasi Nilai Indeks Kekeringan Metode Palmer pada DAS Bedadung

\begin{tabular}{|c|c|c|c|c|c|c|c|c|c|c|c|c|}
\hline \multirow{2}{*}{ Tahun } & \multicolumn{12}{|c|}{ Bulan } \\
\hline & Jan & Feb & Mar & Apr & Mei & Jun & Jul & Agst & Sept & Okt & Nov & Des \\
\hline 2004 & 34,291 & 23,931 & 17,350 & 17,031 & 6,854 & $-2,822$ & $-8,298$ & $-13,601$ & $-20,967$ & $-30,864$ & $-10,279$ & 28,875 \\
\hline 2005 & 4,021 & 9,817 & 19,571 & 16,544 & $-0,034$ & $-6,991$ & $-5,334$ & $-9,780$ & $-16,219$ & $-11,648$ & 6,988 & 30,252 \\
\hline 2006 & 43,765 & 35,467 & 25,027 & 20,509 & 16,299 & 3,632 & $-10,975$ & $-16,521$ & $-22,846$ & $-27,797$ & $-12,798$ & 11,928 \\
\hline 2007 & 0,022 & 11,727 & 20,992 & 15,386 & 6,564 & $-2,833$ & $-6,433$ & $-11,635$ & $-20,576$ & $-17,435$ & 6,209 & 26,819 \\
\hline 2008 & 17,822 & 16,943 & 24,737 & 19,240 & 0,026 & $-7,410$ & $-15,253$ & $-16,943$ & $-24,538$ & $-13,265$ & 19,286 & 26,537 \\
\hline 2009 & 28,525 & 25,632 & 18,813 & 8,559 & 6,911 & 3,563 & $-7,055$ & $-14,109$ & $-16,507$ & $-12,949$ & $-2,263$ & 8,060 \\
\hline 2010 & 38,612 & 24,496 & 17,574 & 17,489 & 15,825 & 5,227 & $-2,146$ & $-4,375$ & 1,555 & 9,916 & 11,098 & 18,791 \\
\hline 2011 & 21,738 & 21,728 & 25,330 & 23,446 & 9,562 & $-3,737$ & $-12,494$ & $-19,123$ & $-23,672$ & $-12,748$ & 9,163 & 22,521 \\
\hline 2012 & 27,959 & 25,524 & 19,733 & 11,975 & 2,733 & $-5,739$ & $-9,845$ & $-15,903$ & $-26,458$ & $-18,761$ & 2,276 & 19,571 \\
\hline 2013 & 34,212 & 27,243 & 16,909 & 12,430 & 10,545 & 8,426 & 1,950 & $-8,412$ & $-18,012$ & $-16,488$ & 5,115 & 28,033 \\
\hline 2014 & 31,656 & 24,013 & 10,645 & 9,742 & 7,107 & $-2,656$ & $-8,184$ & $-13,680$ & $-21,003$ & $-30,992$ & $-10,481$ & 28,992 \\
\hline 2015 & 18,307 & 19,050 & 22,561 & 21,481 & 9,030 & $-2,295$ & $-8,412$ & $-16,400$ & $-25,343$ & $-36,826$ & $-21,695$ & 8,510 \\
\hline 2016 & 12,372 & 19,984 & 18,283 & 7,594 & 7,525 & 6,817 & 2,827 & $-5,120$ & $-3,142$ & 6,877 & 18,462 & 23,077 \\
\hline 2017 & 21,304 & 16,300 & 14,089 & 15,603 & 6,038 & $-1,767$ & $-8,626$ & $-22,199$ & $-21,258$ & $-2,242$ & 17,453 & 24,261 \\
\hline 2018 & 42,275 & 36,538 & 18,444 & 7,943 & 4,336 & $-4,534$ & $-13,280$ & $-24,673$ & $-22,443$ & $-32,672$ & $-22,277$ & 15,867 \\
\hline
\end{tabular}

Sumber: Hasil Analisa

Tabel 4. Nilai Transformasi Box Cox Terstandarisasi (Z)

\begin{tabular}{|c|c|c|c|c|c|c|c|c|c|c|c|c|}
\hline \multirow{2}{*}{ Tahun } & \multicolumn{12}{|c|}{ Bulan } \\
\hline & Jan & $\mathrm{Feb}$ & Mar & Apr & Mei & Jun & Jul & Agst & Sept & Okt & Nov & Des \\
\hline 2004 & 1,145 & 1,149 & 1,265 & 0,532 & 0,073 & $-0,374$ & $-0,481$ & $-1,168$ & $-1,472$ & $-1,525$ & $-0,238$ & 1,093 \\
\hline 2005 & 0,781 & 1,267 & 0,963 & 0,748 & $-0,564$ & $-0,229$ & $-0,280$ & $-1,457$ & $-1,754$ & $-0,565$ & $-0,387$ & 1,477 \\
\hline 2006 & 1,384 & 1,201 & 1,026 & 0,900 & 0,689 & $-0,227$ & $-0,626$ & $-1,078$ & $-1,314$ & $-1,570$ & $-0,660$ & 0,275 \\
\hline 2007 & 0,097 & 1,103 & 1,310 & 0,958 & 0,153 & $-0,053$ & $-0,896$ & $-1,111$ & $-1,613$ & $-1,456$ & 0,422 & 1,086 \\
\hline 2008 & 0,862 & 0,780 & 1,376 & 0,510 & $-0,057$ & $-0,749$ & $-1,269$ & $-1,177$ & $-1,739$ & $-0,394$ & 0,805 & 1,052 \\
\hline 2009 & 1,429 & 1,418 & 0,847 & 0,687 & 0,630 & 0,135 & $-0,772$ & $-1,352$ & $-1,477$ & $-1,306$ & $-0,082$ & $-0,157$ \\
\hline 2010 & 1,066 & 1,518 & 0,628 & 0,787 & 0,186 & $-1,014$ & $-0,850$ & $-1,943$ & $-0,371$ & $-1,040$ & 0,174 & 0,858 \\
\hline 2011 & 0,982 & 1,187 & 1,536 & 0,214 & 0,250 & $-0,698$ & $-0,863$ & $-1,276$ & $-1,374$ & $-1,108$ & 0,065 & 1,085 \\
\hline 2012 & 1,368 & 1,275 & 1,097 & 0,582 & 0,163 & $-0,354$ & $-0,729$ & $-1,184$ & $-1,626$ & $-1,177$ & $-0,288$ & 0,875 \\
\hline 2013 & 1,437 & 1,118 & 0,820 & 0,676 & 0,087 & 0,296 & $-1,105$ & $-1,144$ & $-1,415$ & $-1,376$ & $-0,349$ & 0,956 \\
\hline 2014 & 1,210 & 1,047 & 0,709 & 0,899 & 0,105 & $-0,422$ & $-0,628$ & $-1,130$ & $-1,430$ & $-1,506$ & $-0,233$ & 1,379 \\
\hline 2015 & 1,063 & 1,156 & 1,384 & 1,000 & 0,398 & $-0,117$ & $-0,665$ & $-0,971$ & $-1,475$ & $-1,495$ & $-0,693$ & 0,414 \\
\hline 2016 & $-0,114$ & 1,597 & 0,528 & 0,207 & $-0,093$ & $-0,058$ & $-1,689$ & $-1,909$ & $-0,543$ & $-0,058$ & 0,928 & 1,203 \\
\hline 2017 & 1,195 & 0,598 & 0,728 & 0,781 & $-0,406$ & $-0,308$ & $-0,899$ & $-1,580$ & $-1,678$ & $-0,530$ & 0,730 & 1,370 \\
\hline 2018 & 1,106 & 1,032 & 1,188 & 0,643 & $-0,010$ & $-0,585$ & $-0,841$ & $-1,257$ & $-1,654$ & $-1,024$ & 0,205 & 1,197 \\
\hline
\end{tabular}




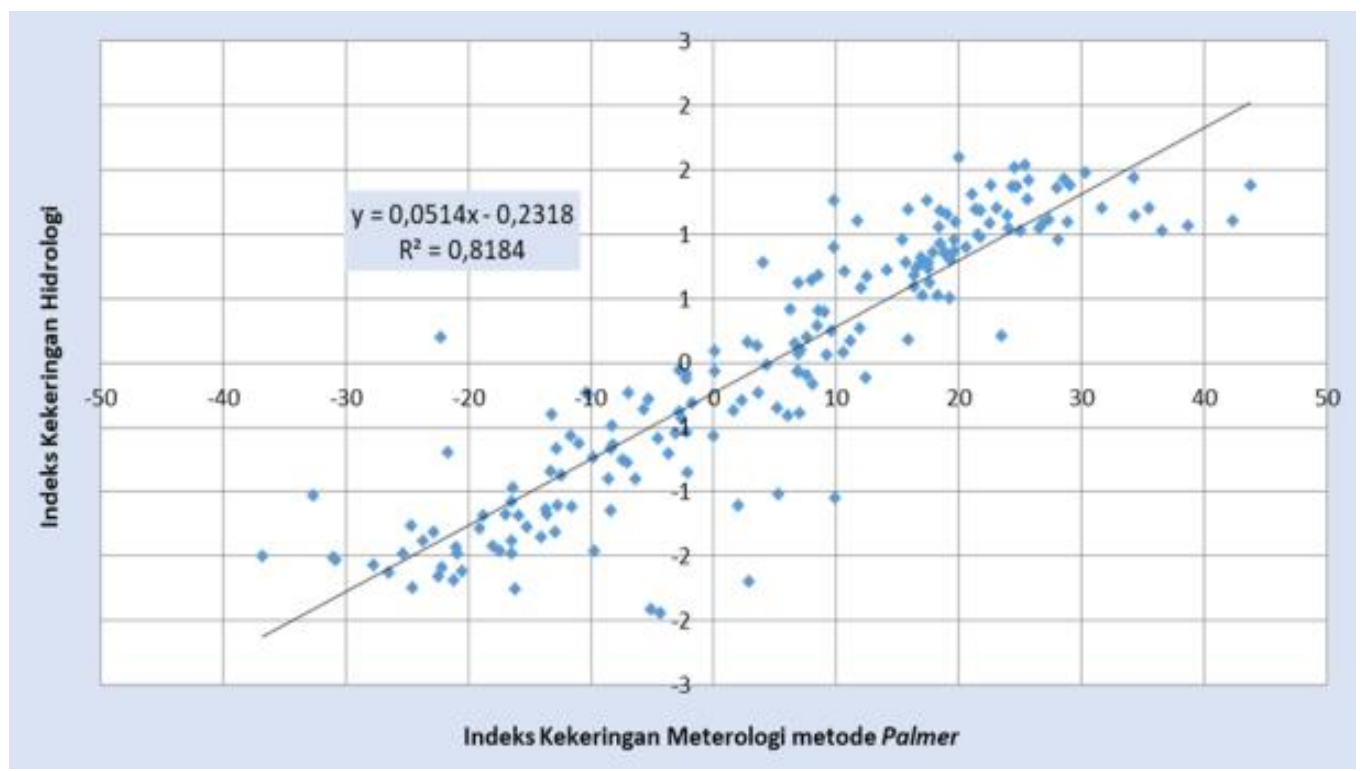

Gambar 9. Nilai R Hubungan Indeks Kekeringan Meterologi dengan Hidrologi Sumber: Hasil Analisa

Gambar 9 memperlihatkan nilai hubungan antara indeks kekeringan meterologi (Tabel 3) dengan indeks kekeringan hidrologi (Tabel 4) yang memiliki nilai $R^{2}=0,82$ hal ini mengindikasikan bahwa kedua indeks kekeringan tersebut memiliki hubungan yang erat satu dengan yang lain. Selain analisa regresi, hubungan kedua indeks kekeringan dapat menggunakan analisa korelasi. Dari koefisien korelasi Pearson, diperoleh nilai $r=$ 0,91 . Nilai ini dapat diinterprestasikan bahawa tanda korelasi positif menyatakan indeks kekeringan meteorologi metode Palmer dan indeks kekeringan hidrologi (nilai Transformasi Box Cox terstandarisasi (Z) Debit AWLR) mempunyai hubungan yang searah. Kita bisa menarik kesimpulan bahwa indeks kekeringan meteorologi yang menunjukan bulan kering, maka indeks kekeringan hidrologinya juga cenderung menujukan bulan kering atau apabila indeks kekeringan meteorologi yang menunjukan bulan basah, maka indeks kekeringan hidrologinya juga cenderung menujukan bulan basah. Selain mempunyai hubungan yang searah, nilai korelasi tersebut menunjukan kedua indeks kekeringan mempunyai tingkat hubungan yang sangat kuat.

\section{KESIMPULAN DAN SARAN}

Dari hasil pengolahan, perhitungan dan analisa dapat diambil kesimpulan sebagai berikut :
1. Besaran indeks kekeringan rerata bulanan metode Palmer, yang menunjukan kategori bulan kering berkisar -1,82 (rerata bulan Juni) sampai dengan -14,14 (rerata bulan September). Indeks kekeringan rerata bulan dapat diketahui sebarannya. Adapun peta sebaran kekeringan rerata bulan dapat diketahui bahwa Kecamatan Panti, Patrang, Jelbuk dan Arjasa mempunyai durasi kekeringan selama 5 bulan pada bulan Juni sampai dengan bulan Oktober. Sedangkan wilayah kecamatan di wilayah studi yang lain mengalami kekeringan dengan durasi yang 4 bulan.

2. Dari gambar antara pola hujan dan debit terjadi kemiripan, pada bulan basah hujan dan debit memiliki nilai yang lebih besar dari pada bulan kering

3. Berdasarkan hasil estimasi koefisien korelasi Pearson, diperoleh nilai $r=0,91$. Nilai ini dapat diinterprestasikan bahawa tanda korelasi positif menyatakan indeks kekeringan meteorologi metode Palmer dan indeks kekeringan hidrologi (nilai Transformasi Box Cox terstandarisasi $(Z)$ Debit AWLR) mempunyai hubungan yang searah. Selain mempunyai hubungan yang searah, nilai korelasi tersebut menunjukan kedua indeks kekeringan mempunyai tingkat hubungan yang sangat kuat. Analisa hubungan regresi memperlihatkan nilai hubungan antara indeks kekeringan meterologi dengan hidrologi yang memiliki nilai $R^{2}=0,82$ hal ini mengindikasikan 
bahwa kedua indeks kekeringan tersebut memiliki hubungan yang erat satu dengan yang lain.

Untuk lebih meningkatkan keakuratan, dalam penelitian selanjutnya disarankan sebagai berikut:

1. Perlu dilakukan studi penelitian di lokasi DAS yang berbeda guna memberikan kesimpulan yang lebih nyata.

2. Untuk mendapatkan hasil yang akurat diperlukan wilayah studi yang lebih sempit dan data hujan historis yang digunakan lebih panjang sehingga didapatkan hasil analisa yang lebih akurat.

3. Dalam penelitian selanjutnya perlu dilakukan verifikasi hubungan debit AWLR dengan debit model.

4. Dalam penelitian selanjutnya perlu dicari tentang hubungan antara kekeringan meterologi, hidrologo dengan kekeringan secara pertanian.

5. Bentuk perhatian secara nyata berupa arahan pengelolaan kawasan bencana kekeringan seperti dibangunnya embungembung desa pada kawasan hulu DAS Bedadung.

\section{UCAPAN TERIMA KASIH}

Kepada Bapak Prof. Dr. Ir. M. Bisri, MS. dan Dr. Ir. Ery Suhartanto, ST., MT., Penulis menyampaikan ucapan terima kasih atas masukan dan bimbingan selama penulis menyelesaikan Karya Tulis ini. Selain itu Penulis tak lupa mengucapkan terima kasih yang sebesar-besarnya kepada Kementerian Pekerjaan Umum dan Perumahan Rakyat dalam hal ini Badan Pengembangan Sumber Daya Manusia dengan Kehendak Tuhan YME telah memberikan kesempatan kepada Penulis untuk medapatkan Beasiswa Pendidikan
Kedinasan jenjang Magister Teknik Pengairan Universitas Brawijaya Malang.

\section{DAFTAR PUSTAKA}

K.V. Suryabhagavan. 2017. GIS-based climate variability and drought characterization in Ethiopia over three decades. Elsevier - Weather and Climate Extremes. Vol. 15 , hal. $11-23$.

Kao, S. dan Govindaraju, R.S. 2010. A Copula-Based Joint Deficit Index for Droughts. Jurnal of Hydrology, Vol. 380, hal. 121-134.

Loukas A., Vasiliades L. 2009. Hydrological respone to meteorological drought using Palmer drought indices in Theassaly, Greece. Desalination 237, hal. 3-21

Mishra, A.K. dan Singh, V.P. 2010. A Review of Drought Concepts. Journal of Hydrology. Vol. 391, hal. 202-216.

National Drought Mitigation Center. 2006. What is Drought, USA. Entry from http://drought.unl.edu/

Peraturan Daerah Kab. Jember No. 1 Tahun 2015 tentang Rencana Tata Ruang Wilayah (RTRW) Pemkab. Jember.

Quiring, S.M., dan Papakryiakou, T.N. 2003. An Evaluation of Agricultural Drought Indices for the Canadian Prairies, Agricultural and Forest Meteorology, Vol. 118, hal 49-62.

Zengchao Hao, Fanghua Hao, Vijay P. Singh, Youlong Xia, Wei Ouyang, dan Xinyi Shen. 2016.A theoretical drought classification method for the multivariate drought index based on distribution properties of standardized drought indices. Advances in Water Resources. Vol. 92, hal. 240-247. 